\title{
ALAIN CORBIN o prazer do historiador
}

Entrevista concedida a Laurent Vidal Tradução: Christian Pierre Kasper

RESUMO

Nesta entrevista, Alain Corbin explica sua paixão pela história, tal como as leituras e os encontros que determinaram sua escolha da história das sensibilidades. Ele detalha algumas das suas grandes obras, precisa sua definição do campo das sensibilidades, e evoca os desafios da biografia dos indivíduos ordinários em história. Ele insiste sobre a necessária atenção do historiador ao inatual, ao insólito e às banalidades do cotidiano. Palavras-chave: Alain Corbin; Teoria da história; Sensibilidades.

\section{ABSTRACT}

In this interview Alain Corbin explains his passion for History, the readings and encounters that have influenced his personal trajectory and historiographic and thematic choices. He comments some of his main works and particularizes his definition of sensibilities, besides to point out the challenges of writing the biography of ordinary people. Corbin affirms that historians need to turn their attention to what is unnatural and unusual, to banalities of daily life.

Keywords: Alain Corbin; Theory of history; Sensibilities.

Nascido em 1936, na Normandia, Alain Corbin estudou na Universidade de Caen. Um de seus então professores, Pierre Vidal-Naquet, lembra-se: "um dos meus primeiros alunos foi Alain Corbin, que considero um dos melhores historiadores de sua geração". 'Seu percurso universitário é uma ilustração desta brilhante carreira: Lycée de Limoges, Universidade de Tours e, enfim, Paris, onde é nomeado professor de história contemporânea na Sorbonne.

De rara erudição, dotado de um estilo de grande qualidade literária, mostrando um rigor analítico sem falha, Alain Corbin permanece todavia um historiador atípico, cuja originalidade se manifesta pela escolha de objetos de estudos inusitados para os historiadores: a história do olfato, da miséria sexual masculina, da paisagem sonora, da sensibilidade ao tempo que faz. Inscrevendo-se no prolongamento das obras iniciadas por Lucien Febvre, Corbin defi- 
ne-se como um historiador do sensível. Vários de seus livros inscrevem-se nessa veia historiográfica: Les cloches de la terre. Paysage sonore et culture sensible dans les campagnes au XIX ${ }^{e}$ siècle (Albin Michel, 1994), Le miasme et la jonquille: odorat et imaginaire social. XVIII e siècles (Flammarion, 1986).

Especialista da história da França no século XIX, ficou também conhecido por seus trabalhos consagrados à história da paisagem, com livros clássicos tais como: Le territoire du vide: l'Occident et le désir de rivage (Flammarion, 1990), ou, ainda: L'homme dans le paysage (Textuel, 2001).

Obteve, no ano 2000, o grande prêmio de história da Académie Française pelo conjunto de sua obra. Em setembro de 2002, a New York University consagrou um colóquio ao estudo de sua obra: "Alain Corbin and the writing of history”. Esta entrevista, realizada na Universidade de La Rochelle, a 21 de novembro de 2003, diante de um público estudantil, volta-se para alguns momentos de seu percurso.

\section{O GOSTO PELA HISTÓRIA}

Laurent Vidal: O senhor pode nos explicar como surgiu seu gosto pela história?

Alain Corbin: Isso é difícil... Lembro-me que, quando eu estava no colégio, gostava da história, mas nunca me questionei. Depois, já na universidade, eu me disse: "vou fazer história". O que aconteceu?

Eu creio, de fato, que isso responde, em primeiro lugar, a uma curiosidade, que me parece fundamental: "Estamos aqui. Como eram as pessoas antes de nós? Como viviam?”. Essas questões propiciam uma verdadeira mudança de ares, e é isso que atiça a curiosidade. Mas, parece-me também, em segundo lugar, que é um prazer, que é preciso que a história seja um prazer. Ouve-se dizer: "Ah! não gosto de história!”. Não se deve fazer história se não for com um grande prazer. Nunca tive a impressão, na minha longa carreira, de realmente trabalhar, mas sempre de fazer o que me interessava. Chamava-se isso, na época clássica, o otium, o lazer cultivado. E eu não lamento essa escolha. Essa curiosidade com relação à história não se esgota, pelo contrário.

Penso também que os lugares, as tradições e a educação influem nisso: eu sou oriundo do campo, do bocage normando, cuja paisagem formiga de igrejas, de abadias, de testemunhos do passado... É possível que essa inclinação para o passado da região na qual eu cresci tenha favorecido o interesse 
pelo passado. Seria preciso fazer estudos sobre a origem geográfica dos historiadores.

LV: Há, contudo, leituras que o marcaram durante sua formação de historiador?

AC: Sim, mas isso já faz muito tempo. É necessário, em primeiro lugar, precisar que eu entrei na faculdade em 1952, há mais de meio século. Naquela época, a historiografia era muito menos rica do que hoje. Não havia livros de bolso, por exemplo. Não havia manuais impressos para os estudantes do ensino superior. Na época, já se falava em Fernand Braudel. O professor que nos falava dele era, de alguma forma, um fanático dos Annales. Fernand Braudel representava sua vanguarda, assim como, aliás, Lucien Febvre. Febvre, cujos artigos acabavam de ser agrupados sob o título Combats pour l'histoire. Todo aquele campo que foi chamado de história das mentalidades - ainda que ele mesmo não o chamasse sempre assim: história das sensibilidades, psicologia histórica... É essa grande corrente de psicologia histórica que percorre a historiografia francesa desde Michelet. Lembro que, em meu grupo de amigos, estudantes de história, dizíamos um ao outro: "Oh, é isso que precisamos fazer, a história psicológica, a história das mentalidades, a história da sensibilidade". Ora, naquela época havia uma concorrência forte da história quantitativa. São os anos em que Pierre Chaunu inventa, aliás, a expressão 'história serial', e em que, sob a influência de François Simiand, faz-se muita história quantitativa. A grande escola dos Annales dividiu-se então em duas correntes: há aquela de Lucien Febvre e Marc Bloch, com - como descendentes - Duby, Marrou, Dupront etc.; e uma história mais quantitativista e serial, com, por exemplo, Le Roy-Ladurie ou Chaunu.

LV: Houve encontros que, na sua formação de historiador, também contaram?

AC: Evidentemente. Uma coisa me impressiona muito: é que freqüentemente os professores são julgados dez ou vinte anos depois. Isto é, não se mede sempre a contribuição de tal ou tal professor. Tive professores dos quais gostei muito: um professor de história da Idade Média, por exemplo, aquele que nos ensinava os Annales, ou, então, no campo da história antiga, um jovem assistente que tinha apenas quatro ou cinco anos de carreira: Pierre Vidal-Naquet, com o qual mantenho forte amizade. 
Gostaria de dar um exemplo. Havia um professor de história da Revolução Francesa, Marcel Reinhard. Eis como dava suas aulas: primeira meia hora, uma narrativa, uma pilhagem ou um incêndio de castelo, por exemplo, na época do Grande Medo. Em seguida, ele retomava aquela história de pilhagem para tentar ver o que ela podia fornecer do ponto de vista historiográfico. Aquilo não nos agradava muito. Pensávamos no exame. Tínhamos a impressão de que não havia muito a retirar do relato da pilhagem, e que seríamos reprovados. Com o tempo, me dei conta de que sua maneira de proceder era extremamente rica, misturava o concreto, o efeito de realidade, com a análise das lógicas de comportamento: aquilo era extremamente forte. Creio que tudo que é da ordem da experiência humana é útil para o historiador, mesmo se essa experiência deriva de narrativas. Mais vale termos o maior número de experiências humanas possíveis na existência, quando nos pretendemos historiador: isso facilita a adoção de uma ótica compreensiva com relação às pessoas do passado.

LV: O senhor falava, há pouco, de duas correntes dos Annales. Gostaria justamente de evocar sua tese e seu percurso entre a escolha do assunto e a publicação da tese. Parece-me que isso ilustraria, talvez, justamente a passagem de uma corrente para a outra. Começar com um estudo de história serial, estudo dos preços, das rendas sobre "le Limousin et les Limousin au XIX ${ }^{\mathrm{e}}$ siècle", e chegar a um resultado talvez mais próximo das preocupações da antropologia histórica com aquele título Arcaísmo e modernidade, onde o senhor fala dos migrantes, dos sedentários, e daquela descoberta da organização da sociedade em torno desses dois grupos.

AC: É preciso dizer que na época, quando se queria estudar uma região, era necessário dirigir-se ao 'ditador', se posso assim dizer, isto é, ao grande historiador Ernest Labrousse, que, de Paris, distribuía os territórios franceses como se fossem prefeituras. Georges Dupeux tinha trabalhado sobre o Loiret-Cher, ${ }^{2}$ André Armengaud sobre a Aquitânia. Havia ainda uma dezena de teses em andamento. Então fui lá, timidamente. Era o final dos anos 50 . Eu tinha acabado de ser nomeado no Liceu de Limoges. Labrousse não estava interessado - "mas eu vou encaminhá-lo para um professor de história econômica de Clermont-Ferrand que vai se encarregar de você”. Fui então orientado por um professor de história das técnicas e da economia: Bertrand Gille. E o importante é saber que aquelas teses ditas "labrousseanas", que cobrem ao menos um terço do território francês, eram fundadas na convicção de que 
era preciso estudar as infra-estruturas, a economia, notadamente as rendas, e depois estudar a sociedade para chegar, finalmente, às atitudes políticas e a uma história das mentalidades. Do porão ao sótão, de certa forma. Então eu comecei. Mas no Limousin, nada funcionava. Como calcular a renda de um camponês daquela serra, que vivia em parte de castanhas, de caça, que tinha uma horta, que pescava? Tudo isso era dificilmente quantificável.

Então, passados dois anos, o professor Bertrand Gille disse-me: "Você sabe, desta maneira não vai chegar muito longe”. Depois, como ele era professor de história das técnicas, me disse também: "eu vou lhe dizer o que o emperra; é que aquelas administrações não tinham muito papel, e os funcionários mal dominavam a escrita e a leitura, então, todas essas estatísticas, eu não acredito muito nelas". Isso me levou a uma mudança de rumo e a me interessar pelo que, de fato, me agradava mais: o comportamento biológico - a alimentação, a história cultural, a escola, as formas da miséria, a reação à miséria, enfim, todas aquelas séries de coisas que foram reagrupadas sob o título de antropologia histórica. Abandonei, então, grande parte daquele modelo labrousseano, para me interessar por este outro problema: "Por que, desde a Segunda República, desde o início do sufrágio universal, os Limousins votaram sempre na esquerda?". Eu queria encontrar as chaves, as raízes dessa atitude: a migração temporária para Paris, da qual você falou, a estrutura social, a fraqueza da nobreza, a influência dos homens da lei, a estrutura familiar, enfim, toda uma série de chaves, de validade limitada, pois, com o tempo, acredito cada vez menos nas explicações mecanicistas na história.

A causalidade é tão complexa nos fenômenos históricos que eu não acredito mais no velho plano: "as causas, os fatos, as conseqüências". Tomemos a Primeira Guerra Mundial: não creio absolutamente que se possa, no estado atual das coisas, e até no futuro, explorar a extrema complexidade dos mecanismos que desencadearam uma tal aventura. Permaneço, portanto, muito cético com relação a esse método, mas não quero lançar confusão sobre o auditório.

\section{O HISTORIADOR E A DISCREPÂNCIA DAS SENSIBILIDADES}

LV: Passemos da tese para uma pequena seleção de sua obra, para que o senhor nos esclareça certos aspectos de sua abordagem. Comecemos com $A$ aldeia dos canibais. ${ }^{3}$ Como o senhor chegou àquele linchamento público na aldeia de Hautefaye, e em que momento veio essa intuição de que era preciso, 
justamente, tentar explicar não as causas, mas antes o sentido daquela atitude da população?

AC: Escrevi aquilo em 1989-1990. Foi, portanto, 30 anos depois do que estávamos comentando até agora. Quando eu trabalhava sobre o Limousin, tinha ouvido falar daquela aventura de Hautefaye, porque é bem perto. $\mathrm{O}$ Nontronais se parece muito com o Limousin: é, de certa forma, um pedaço do Limousin colocado na Dordogne. Portanto, eu me havia interessado por aquele caso... E 30 anos mais tarde, pensei que havia aí alguma coisa curiosa: nosso conhecimento sobre aquele acontecimento remete a uma atitude bastante grave, a meu ver - a prática da história teleológica. Explico. Fez-se uma história do século XIX em função de sua conclusão, em função do que aconteceu. A República triunfou. Então, já que a República triunfou, a inclinação natural consiste em analisar o conjunto do século XIX como aquele da marcha para a República, do triunfo da República. É uma forma de história que se poderia chamar de genealógica — perfeitamente legítima, aliás - , que pretende encontrar as raízes de um fenômeno. Mas o risco dessa história é o de fazer perder a realidade da substância daquele século. Chegou-se a esquecer que o século XIX, na França, é um século dominado pela presença de soberanos. Se você adicionasse todos os reinos dos reis e dos imperadores, isso ultrapassa, e muito, os momentos republicanos.

O caso de Hautefaye parecia-me apontar esse perigo, essa complexidade, por tratar-se de uma revolta de camponeses que atacam aqueles que pensam ser republicanos. Então, o que me interessava era buscar a lógica de cada um dos atores daquela aventura, e creio que é um método histórico extremamente frutífero quando se faz uma história do acontecimento. Em vez de procurar pelas causas, buscar colocar-se na pele dos atores, e reconstituir a lógica de cada um deles, ou de cada um dos grupos envolvidos, para melhor entender, em seguida, o enfrentamento e os resultados. Tudo isso funda-se sobre a análise dos sistemas de representação do mundo, de representação do além, do outro, do animal, do vegetal, do humano etc., para entender como o texto que se tem debaixo dos olhos pôde se formar.

Eu queria, então, tentar me colocar na pele daqueles camponeses para entender sua lógica. Mesmo que ela nos pareça totalmente aberrante. E, em paralelo, eu precisava tentar desvendar o sistema de representação das elites de Périgueux ou de Paris, frente a esses atores cujo gesto eles não entendiam. Creio, portanto, que aquela aventura sangrenta foi, antes de tudo, fruto de um 
choque de representações do mundo e da política, e de uma incompreensão recíproca.

Podemos tratar de muitos acontecimentos desta maneira, mas aquele possuía outras dimensões de real interesse para o historiador: mostrava que, com relação à violência e ao homicídio, havia limiares de tolerância que eram diferentes segundo as categorias sociais - é sempre o caso. Testemunhava também fenômenos de inércia na história: em Hautefaye, formas de sensibilidade tinham sobrevivido, de alguma forma, à evolução do século XIX, que se caracterizava por uma intolerância crescente com relação ao massacre. Creio que é também algo importante. O que define a história cultural? De certa forma, os indivíduos que vivem um mesmo período não são contemporâneos. A história cultural é feita de recobrimentos, de sedimentações, de inércias, isto é, não se sente as mesmas coisas, segundo uma série de critérios: o sexo, a idade, a categoria social, o local geográfico, a tradição, ou a cultura que se recebeu. O historiador da cultura deve sempre tentar entender essa complexidade, essa simultaneidade de atitudes muito diferentes segundo os indivíduos e segundo os grupos. E o caso de Hautefaye, que é, afinal, um caso muito pequeno - salvo para aquele que foi assado - , tem o mérito de poder evidenciar que aquelas pessoas não tinham, de forma alguma, a mesma sensibilidade: uns toleram o que outros não toleram.

LV: O senhor citou várias vezes este termo, 'sensibilidade', e vamos falar sobre ele. O senhor conhece certamente esta frase de Proust: "uma hora não é uma hora, é um vaso cheio de perfumes, de sons, de projetos e de climas". E eu acho que se poderia colocá-la de epígrafe para apresentar sua obra: Le miasme et la jonquille, odorat et imaginaire social, ${ }^{4}$ Le désir de rivage, ${ }^{5}$ Les cloches de la terre: paysage sonore et culture sensible. ${ }^{6}$ No livro de entrevistas com Gilles Heuré, é sob o título de "historiador do sensível" que o senhor se apresenta ou é apresentado. ${ }^{7}$ Pode nos explicar, tomando, talvez, o exemplo de Le miasme et la jonquille, o que é um historiador das sensibilidades?

AC: Eu já mencionei a necessidade, para o historiador, de tomar como ponto de partida a maneira como as pessoas que se estuda representavam-se, e de entender a coerência de suas representações. Você reparou como a quase totalidade das revistas que se encontram nas bancas tratam da mesma trilogia: sentimento, paixão, emoção? E quando você consulta os trabalhos dos historiadores, há bem poucos estudos sobre a emoção, o sentimento e a paixão. Ora, Lucien Febvre, desde 1938, admirava-se: "não temos uma história 
do amor ... não temos uma história da alegria", ${ }^{8}$ e ia enumerando toda uma série de sentimentos. No seu livro sobre l'incroyance au XVI ${ }^{e}$ siècle, ele consagra um capítulo à maneira como os franceses daquele tempo sentiam. E nota que, desde aquela época, assiste-se a um processo de racionalização que poderia ser comparado com o processo civilizador do qual fala Norbert Elias, ${ }^{10}$ segundo o qual os sentidos, tais como o olfato, recuaram com relação aos sentidos julgados nobres desde Platão: a visão e a audição. Apelava, portanto, para uma história da utilização dos sentidos, da sensibilidade, e da balança estabelecida entre os sentidos, das correspondências eventualmente estabelecidas entre eles. Tudo isso forma uma antropologia sensorial histórica. Ele não foi seguido. Certamente, Robert Mandrou, no seu livro L'introduction à la France moderne $e^{11}$ retoma o projeto de Lucien Febvre neste campo. Mas essa abordagem foi muito pouco desenvolvida.

Ora, já que você fala do Miasme et la jonquille, havia, parece-me, uma expectativa social muito forte. Se esse livro teve tanta repercussão, é - eu não me iludo - por causa do romance de Patrick Süskind, Le parfum. ${ }^{12}$ Süskind inspirou-se no meu livro para escrever seu romance. O que tinha chamado muito minha atenção ao redigir o livro precedente, dedicado à prostituição (Les filles de noce), ${ }^{13}$ é que quando se descreve a Paris do século XIX, as prostitutas, seus locais de atividade etc., as ocorrências olfativas são extremamente numerosas. Havia aí algo de surpreendente. Lucien Febvre nos deixa entender que o olfato tinha regredido: ora, depois da Revolução, a medicina clínica, então em expansão, dá muita atenção à observação sensorial. Olhase, escuta-se, às vezes cheira-se o doente. É possível também que a Revolução tenha destruído uma harmonia das ordens sociais, e que a necessidade de vencer a opacidade do social, das profundezas sociais e dos alicerces sociais em Paris, tenha levado a valorizar a ocorrência olfativa.

Eu quis estudar isso. Parece-me que eu mostrei que "o imaginário social" — é o subtítulo do livro - , isto é, as maneiras pelas quais se representa o outro, deve muito à olfação. Intitulei um dos capítulos como "O fedor do pobre”. As elites esforçam-se em desodorizar, em não deixar a perspiração, isto é, o odor do eu, transparecer - era o assunto de Süskind. Não é o caso do povo, que costuma ser visto sob a forma de uma ameaça — como o tinha mostrado Louis Chevalier. ${ }^{14}$ A olfação, por si só, permite detectar o pobre: os médicos pensam então que as doenças são transmitidas, não pelo contágio, mas pela infecção - sobretudo da água e do ar. Na perspectiva dessa medicina infeccionista, o olfato serve para designar os perigos: perigo da fermentação dos alimentos, da podridão das carnes, do confronto com o outro, que, justamen- 
te, cheira mal. Esse processo de distinção social pela desodorização me pareceu essencial para entender a sociedade do século XIX. Veja o Germinal de Zola: a mulher do grande patrão quer abrir as janelas depois da visita de uma delegação de operários. Seria isso, então, a história das sensibilidades: identificar a utilização dos sentidos que permitiu construir imagens do outro, dar forma ao imaginário social.

LV: Continuemos este passeio pela sua obra, sem respeito pela ordem cronológica. Há uma investigação coletiva que o senhor conduz sobre o advento dos lazeres, ${ }^{15}$ que cruza, ao que parece, com a história das sensibilidades e a história das sociabilidades.

AC: Sim, mas neste caso, tratava-se de uma encomenda: é, portanto, um pouco diferente. Mas creio que é um outro aspecto muito interessante de se estudar. O sociólogo Georges Gurvitch tinha proposto análises extremamente precisas da multiplicidade dos tempos sociais. ${ }^{16}$ Cada sociedade vive no interior de um arcabouço temporal, e mesmo, cada indivíduo. Vivemos em sociedades, digamos, cristãs, para as quais o tempo não é cíclico: o tempo é linear e se organiza na espera do retorno do Cristo. Contamos, portanto, os anos desde a presença do Cristo. Se fôssemos hindus, não seria a mesma coisa. Gurvitch já havia mostrado que o tempo da nobreza não era o tempo da burguesia - ainda no século XIX — , apesar das misturas. É, para a burguesia, um tempo da poupança e da construção do patrimônio, que não é aquele da dissipação aristocrática. As profissões, também tinham sua própria temporalidade: assim, os pescadores não tinham a mesma relação com o tempo que os empregados de escritório. Aí está um objeto histórico interessante, que nos remete à história das sensibilidades.

O século XIX é marcado pela aprendizagem dos tempos curtos. Você está acostumado agora com os centésimos de segundo, especialmente por causa das performances esportivas. Ora, o século XIX fez a aprendizagem do minuto, quer dizer, da precisão. Em muitos textos que tinha estudado para escrever Les cloches de la terre, dizia-se: "isso durou o tempo de um Pater", isto é, da oração "Pai nosso", ou "isso durou o tempo de uma Ave", o que deve significar entre três e cinco minutos.

É preciso também levar em conta um outro fenômeno que toma forma naquela época: a laicização do tempo. O minuto de silêncio é um exemplo de rito laicizado. Tomemos o debate que se desenrola hoje em torno da supressão de um feriado. Eu tinha, na ocasião das cloches de la terre, reencontrado 
uma carta de Portalis ao primeiro cônsul: havia festas demais, segundo ele, feriados demais. Estuda, então, a questão e conclui: "importa é que o povo trabalhe". E, em função desse axioma, decide reduzir para quatro os dias de festas conservados: Todos os Santos, Natal, Ascensão, Assunção. Elimina, assim, toda uma série de festas religiosas. Hoje — veja, quando eu falava em arcabouço temporal - existem festas laicas que vieram se enxertar: as duas vitórias, se podemos assim dizer - 11 de novembro e 8 de maio $-{ }^{17} \mathrm{o}$ dia do trabalho - que se confunde com a antiga festa de Louis-Philippe - e o Primeiro de Janeiro. E como havia festas religiosas muito importantes, como a Páscoa e o Pentecostes, juntou-se a elas a segunda-feira seguinte. Temos, então, hoje, quatro festas religiosas conservadas, quatro festas propriamente laicas, e dois dias adjuntos a festas religiosas. Nosso arcabouço temporal dos feriados é assim majoritariamente referido à religião. Mas se você perguntar para as pessoas, na rua, o que é a Assunção, você talvez não receberá muitas respostas, e pouco mais sobre o Pentecostes.

O arcabouço temporal de nossas sociedades é assim marcado pela vitória progressiva de um tempo monocrômico. No século XIX, um artesão pode ser interrompido: vem-se buscá-lo, vai fazer outra coisa, volta, e assim por diante. Hoje, isso não parece mais imaginável. Os tempos são mais determinados. A aritmética dos dias é muito mais nítida. Lembro que nós queríamos fazer, com Michelle Perrot, uma investigação sobre o nascimento da agenda. Você não se dá conta de quanto isso foi importante, porque agora todo mundo tem uma. Quando comecei como professor do secundário, eu não tinha agenda: havia memorizado minhas horas de aula na semana, não marcava horas, e se eu devia jantar com amigos, lembrava que era na sexta ou no sábado. Hoje, parece absolutamente impensável viver sem agenda: tudo desaba. É uma prova da força do tempo determinado.

É, portanto, em razão de todas essas questões que eu pensei ser talvez interessante coordenar um livro sobre o advento dos lazeres, porque esse advento é evidentemente muito ligado às modificações do arcabouço temporal. Existem dois modelos de lazer, dos quais, aliás, ainda não saímos. Há o modelo do lazer cultivado, o otium antigo. Jean-Pierre Chaline bem mostrou que, no século XIX, numerosos médicos, magistrados, subprefeitos, não tinham muito que fazer. ${ }^{18}$ Ser burguês, nos diz Chaline, não é tanto ter muito dinheiro, é dispor de seu tempo, ter o domínio de seu tempo. A partir daí, faz-se o que se quer: pode-se ir para as reuniões da sociedade de sábios, ser eleito vereador, praticar a filantropia e cultivar-se: conversação, meditação filosófica etc. É o otium antigo de Cícero e Sêneca, por exemplo. Há, também, o tempo 
de lazer consagrado à recriação da força de trabalho: aquele que trabalha o tempo todo deve parar absolutamente, porque está esmagado. Esse é o domingo desejado pela Igreja, e que suscitou tantos debates no século XIX.

Esses modelos continuam postos hoje, e deslocou-se para o trabalho toda uma série de atividades que não eram consideradas como tais no século XIX. Pois aqueles indivíduos que praticavam o otium antigo eram freqüentemente muito ocupados. As damas de caridade cumpriam o que seria para nós trabalho social; o trabalho intelectual é uma noção do século XX: Montesquieu certamente não se considerava como trabalhador intelectual, e, no entanto, deus sabe como trabalhava na sua biblioteca! Tomo esses dois exemplos, mas há toda uma série de outras maneiras de viver que caíram na esfera do trabalho e que não lhe pertenciam antes. Isso nos remete para o domínio das representações do tempo e das representações de si.

Tomemos um outro exemplo, concernente ao século XX: a necessidade absoluta da previsão. Lembro-me que, quando eu preparava minha tese, à noite, ao sair dos arquivos, passava diante da Ópera, e, se aquilo me interessava ("ah, é Mozart"), pegava um ingresso e entrava. Agora, é preciso reservar com três meses de antecedência, no mínimo. A mesma coisa para uma exposição. Lembro-me que, durante meus primeiros anos de professorado, eu pegava meu " $2 \mathrm{CV}$ " ou meu " $3 \mathrm{CV}$ ", ${ }_{19}$ e partia ao acaso para a Europa central, para a Turquia etc., e à noite procurava um quarto de hotel, sem ter preparado absolutamente nada. Isto me parece quase impossível hoje: a necessidade de previsão limita nossa liberdade. É mais um exemplo de fenômenos que concernem à história do tempo. Mas, então, como se livrar disso - você vai me perguntar - como reencontrar a liberdade? É difícil imaginar-se completamente desconectado da sociedade.

LV: Thierry Paquot evoca justamente uma arte de resistência a esse tempo imposto, a esse tempo mercantil: a arte da sesta. ${ }^{20}$

AC: A sesta, sim. Mas me permita um outro exemplo. Nos meus tempos de estudante, era possível sair para dançar às nove da noite. Hoje, isso parece estapafúrdio. O horário recuou continuamente: dez horas, meia-noite, uma da manhã. Inversamente, se um de seus amigos diz: "Organizei uma festa formidável, você vem?” — “Quando?” — “Ảs nove da manhã”, isso vai parecer uma total incongruência. Você não pensa que será possível divertir-se, de qualquer maneira que seja. Da mesma forma, surgiu o hábito de mudar de boate ao longo da noite. Na minha geração, ficava-se no mesmo lugar. Agora, em 
Paris, pelo menos, é preciso mudar de lugar. Mal chegamos a um lugar, temos de ir para outro. Véronique Nahoum-Grappe chega à conclusão de que talvez o grande momento da noite acontece quando não estamos mais nem em um, nem em outro dos lugares escolhidos, mas justamente durante um dos deslocamentos. Tudo isso faz parte do arcabouço temporal. Simone Delattre escreveu um livro - As doze horas negras ${ }^{21}$ — para estudar a invenção do noctambulismo. É mais um grande fenômeno histórico do século XIX. Todos esses exemplos estão, portanto, no coração da história do tempo, que constitui um campo de pesquisa a ser ainda explorado.

\section{VIAGEM AO DOMÍNIO DAS SOMBRAS}

LV: Tomemos um outro livro, sobre o qual o senhor foi levado a se explicar longamente: Le monde retrouvé de Louis-François Pinagot: sur les traces d'un inconnu (1798-1876) [O mundo reencontrado de Louis-François Pinagot: no rastro de um desconhecido]. ${ }^{22}$ Sua intenção era conduzir uma pesquisa sobre "a atonia de uma existência comum". O senhor explica, na introdução, que passou muito tempo, a partir de 1995, a identificar um indivíduo que não deixou nenhum vestígio no curso de sua existência - um tipo de novo soldado desconhecido, em suma - , para "apoiar-se sobre o vazio e o silêncio a fim de aproximar um Jean Valjean que nunca teria roubado pão”. E, para isso, o senhor propõe usar uma técnica, que é a técnica cinematográfica da câmera subjetiva para recriar "o possível e o provável, esboçar uma história virtual da paisagem, da sociedade habitual e dos ambientes”. O senhor aceitaria voltar novamente a essa experiência?

AC: Trata-se, efetivamente, de uma experiência. Entrei pela primeira vez em arquivos em 1956, e você está falando de 1995, ou seja, 40 anos depois: você sabe que não se pode fazer sempre a mesma coisa - seria maçante. E se a gente não se dá prazer, está perdido. Como a idéia me veio? Foi no departamento da Orne, no pequeno município de onde vem minha família: entro um dia no cemitério, e vejo que metade dos túmulos tinham sido destruídos por um trator. Tive medo, em primeiro lugar, que túmulos que me dizem respeito, aqueles de meus antepassados, fizessem parte do lote. Não era o caso. Mas pensei, mesmo assim: aqueles túmulos, eu os via com minha avó quando era pequeno, e agora estão destruídos. Não sobrou nada deles, ora, não eram tão longínquos aqueles que estavam enterrados aí. Fui então levado a 
uma meditação sobre o desaparecimento. Quase dei este nome ao livro: "Viagem ao domínio das sombras", como Virgílio indo aos infernos! Nossos bisavós - conseguimos apreender. Tataravós - começa a ficar complicado. E, se for o caso de ir mais além, você não sabe mais sobre seus antepassados do que sobre as pessoas da pré-história: estão desaparecidos, definitivamente. É o que leva tantas dezenas de milhares de genealogistas aos depósitos de arquivos. Vão reencontrar avô, bisavô, desse jeito eles conseguem voltar no tempo, mas só obtêm nomes. Quis, então, tomar um daqueles e tirá-lo da sombra. Uma ressurreição, em suma. Mas você sabe que eu fui criticado, a esse respeito? Lembro-me de uma estudante de mestrado que me retorquiu, eu não tinha o direito de fazer aquilo: "não tenho a menor vontade de que, daqui a 150 anos" me disse, "alguém venha me buscar assim".

O que fazer, então? O melhor, pensei, é talvez ir aos arquivos e proceder ao acaso. Tinha achado isso divertido. É fácil deixar agir o acaso: nos arquivos da Orne, em Alençon, estão conservados os registros de estado civil, por município. Você não olha, coloca o dedo sobre um nome: "zás! pronto". Caio sobre o pequeno município de Origny-le-Butin. Era perfeito. Quatrocentos habitantes na época, 250 hoje. Há, aliás, só - ou quase - parisienses que compraram casas de campo no município. $\mathrm{O}$ mais engraçado é que os arquivistas haviam pedido que eu preenchesse uma ficha de inscrição: "sobre o que o senhor trabalha? - Não sei, mas vou lhe dizer daqui a quinze minutos". Então pedi as tabelas decenais - casamentos, óbitos etc. - e escolhi três nomes. Um morreu com vinte e poucos anos, portanto não me interessava. $\mathrm{E}$ havia aquele Louis-François Pinagot, que viveu 76 anos e que tinha atravessado o século, praticamente. Pensei: “é ele”. Não se toma uma tal decisão sem emoção: "Agora vou trabalhar — quanto tempo, não sei, sem dúvida vários meses - , sobre esse senhor que estava ali, completamente adormecido". E não conseguia me impedir de pensar: "se há uma outra vida e eu a encontrar, será surpreendente”. Procurei, portanto, tudo que eu poderia saber.

Mas há uma outra razão que me levou a fazer aquilo. Tinha participado da História da vida privada ${ }^{23}$ em 1986 e escrevera então duzentas páginas sobre o íntimo. Alguém tinha me dito que só falava do íntimo das elites. Das elites... certamente, porque não se pode estudar a intimidade, a vida privada, senão daqueles que deixaram alguma escrita de si (um diário íntimo, correspondência, uma autobiografia), ou daqueles que foram objeto de uma descrição muito precisa por parte de observadores. Podemos imaginar um grande homem que não deixou uma escrita de si, mas de quem se falou tanto, de quem se fizeram tantos retratos, que podemos penetrar sua intimidade. Mas 
são quantas, essas pessoas? Aquelas críticas eram idiotas, porque não podemos fazer as coisas de outro jeito: fora esse talvez $1 \%$ de pessoas que deixaram uma escrita de si, o desaparecimento é irremediável. E eu queria mostrálo com o exemplo de Louis-François Pinagot. Portanto, procurei realmente, e encontrei muitas coisas: "ele media tanto", "casou tal dia", "teve tantos filhos", "tinha uma vaca", "votou", "não votou”, "absteve-se em 1848”... Vasculhei tudo isso. Mas seus sentimentos, suas emoções, suas paixões: nada. E é o caso de 99\% das pessoas do século XIX.

Lembro que eu participava de uma reunião com Jacques Le Goff, no curso da qual ele disse que, no que diz respeito à Idade Média, há, no máximo, quatro pessoas que podemos conhecer um pouco: São Luiz, de quem ele fez a biografia, Frederico II, o imperador, e, não me lembro, talvez São Bernardo. Temos biografias de outros personagens, de Clóvis, por exemplo, mas é como com Louis-François Pinagot: fala-se de todo tipo de coisas em torno dos problemas do reino, mas sua intimidade, não se penetra nela. É o que tentei mostrar. Já que não se pode fazer um livro com indicações do tipo "ele media tanto, tinha tanto etc.", pensei que era talvez a ocasião de ressuscitar o que havia à sua volta. Podemos, por exemplo, começar pelo judiciário: é interessante, a justiça de paz, o tribunal de polícia. Procurei por toda parte: aquele coitado não fez nada. Isto é, não se embebedou uma vez na vida, senão eu o teria visto, porque ele não se mexeu. Não roubou galinhas, não cortou lenha na floresta, enquanto seu pai foi pego nove vezes, suas primas também. Ele não. Eu não o fiz de propósito. Fui ver no seu lugarejo da Basse Frêne. Encontrei os vizinhos, os quais tiveram histórias. Você falava em câmera subjetiva: é justamente isso. Eu não conheço Pinagot, mas posso ver o que ele via. Eu quis me colocar no lugar dele. Então fui a pé até sua aldeia: percebi que a Basse Frêne ficava a um quilômetro e oitocentos metros da cidade, que era uma descida, o que não é indiferente. E na cidade, fui ver o que tinha. Ele casou sua filha com um alfaiate. Ele fabricava tamancos, eu vi onde eram as lojas daqueles trabalhadores da floresta. Pude assim reconstituir o mundo reencontrado de Louis-François Pinagot.

Não pretendo que seja um método a ser utilizado. Dito isto, encerrei, na minha rede de historiador, Pinagot e seu mundo. Se tomarmos 25 Louis-François Pinagot e 25 "mundos" daquelas pessoas num pequeno cantão ou num quarto de cantão, vamos acabar por conhecer aquele cantão e as pessoas que ali viviam, talvez melhor de que pelo viés da história labroussiana, da história somente quantitativa.

O fato é que, quando estuda a história da vida privada e a história do ín- 
timo, o historiador é condenado a evocar apenas pessoas que praticaram a escrita de si, ou que foram colocadas sob uma luz particular, seja da polícia, seja do confessor, seja do médico.

LV: Esse trabalho sobre Louis-François Pinagot coloca, com efeito, a questão do indivíduo: como o historiador pode apreendê-lo?

AC: Em massa. A história social apreende-o em massa. Ela deduz. Não é nem a história da singularidade, nem a história da subjetividade. Acho que os historiadores praticaram por impostura. Deixaram acreditar que podiam fazer uma história do povo, daquelas pessoas que não tinham deixado vestígios. Mas é preciso, contudo, ter a coragem de dizer que não se pode fazer a história daquilo, mas uma história em massa: calcular taxas de natalidade, de nupcialidade, de mortalidade etc., tudo que encontrei para Louis-François Pinagot. Mas não se penetra absolutamente nas mentalidades. É evidentemente prático para os historiadores: isso facilita as declarações peremptórias. O problema, para o historiador, é de detectar, e não de decretar. Ora, eu vivi uma história social que era em grande parte decretada. Decidia-se que as massas eram assim, mas nada o comprovava. Por exemplo, não sei nem um pouco em que votou Louis-François Pinagot. Evidentemente, podemos saber quanto houve, no município, de sim e de não. Mas além disso, não se pode saber. Mas talvez não seja interessante fazer uma história do indivíduo.

\section{OS DESAFIOS DO INATUAL}

LV: Tomemos um outro tema sobre o qual o senhor se debruçou longamente: o inatual. Em Les cloches de la terre, o senhor diz "que convém dar uma atenção particular ao inatual, ao insólito, ao que é decretado irrisório. Sem dúvida, é preciso tentar um estudo da gênese da insignificância, depois da evolução e da difusão das formas da incompreensão". O senhor pode precisar o que é o inatual para o historiador?

AC: Essa noção recobre dois aspectos bem distintos. Há, em primeiro lugar, o velho problema, muitas vezes enfatizado por Lucien Febvre, do anacronismo psicológico, que consiste em projetar na mente das pessoas que estudamos nossa própria maneira de ver o mundo. Isto coloca, por exemplo, o problema da legitimidade da biografia. Gostaríamos de pensar que aquelas 
pessoas eram "irmãos de inquietudes", para retomar a bela fórmula de André Maurois. Eu também poderia ter estado perto de Cleópatra: teria, então, me comportado como Júlio César? Evidentemente, isso faz viajar no tempo, isso embriaga, é tão apaixonante quanto ler um romance policial, mas é errado: isso não pode ser o método certo. Apenas um historiador familiar aos pensamentos de Júlio César pode se arriscar a escrever "Sem dúvida, Júlio César pensou que... Pode-se imaginar que, transpondo o Rubicão...”. É o básico da história: evitar o anacronismo psicológico.

Enfiar a pele dos outros é muito difícil, e mais ainda quando se trata daqueles que não são muito afastados de nós no tempo. Tome o exemplo do debate violento que se dá atualmente sobre a Primeira Guerra Mundial. Há aqueles que dizem: "os soldados foram para a guerra porque os policiais colocaram-lhes as baionetas nas nádegas. Durante aqueles quatro anos, milhões de homens, na Europa, foram apanhados pela força pública". E há a tese de Stéphane Audoin-Rouzeau, ${ }^{24}$ que diz, em substância: "Mas cuidado, eles já tinham sido convencidos, sob a Terceira República, de que era preciso defender a pátria, defender o solo, a família, que era seu dever: havia, portanto, um certo consentimento, que oscila, evidentemente, segundo os meses, as circunstâncias, os lugares". São duas maneiras de ver... E, entre as duas, a tese lógica hoje, na hora da guerra "zero morte", é dizer que eles foram forçados a ir para a guerra, porque é difícil entendermos que tenha havido voluntários. E, no entanto...

É isso, portanto, o problema do inatual. Para Alphonse Dupront, ${ }^{25}$ a grande qualidade do historiador é "a candura", isto é, a capacidade de esquecer. Digo freqüentemente que, frente a um documento, é preciso deixar emergir o sentido, não se deve impô-lo. Isso obriga o historiador a refletir sobre seus procedimentos: "Não estou enfiando aquilo dentro do que eu penso, dentro do que eu quero, dentro de minha 'caixa'?".

Um dos momentos mais interessantes para o historiador que trabalha em arquivos, ou, aliás, em biblioteca, é o tempo do deslocamento. Se é preciso meia hora de caminhada, temos o tempo de pensar: "Vejamos, vou lá... com quais intenções? O que eu quero ver? O que vou encontrar?” E depois, quando se volta - é também muito importante a reflexão ao sair dos arquivos ou da biblioteca - pensa-se: "Bem, o que encontrei, hoje? Como vou poder organizar aquilo?”. Essas interrogações podem ajudar, às vezes, a lutar contra as interpretações abusivas.

Mas o inatual recobra uma segunda significação: é um convite para dar uma atenção particular a pequenos objetos, a detalhes. A história do detalhe é, aliás, uma tendência dos historiadores da literatura: Flaubert queria fazer a 
história do nada. Escreve, até, na sua correspondência, que se deveria fazer "a história de um pedaço de grama”. Isso vai muito longe... Há, com efeito, objetos históricos de tamanhos diversos, e, entre eles, objetos muito pequenos, portadores "de uma forte carga de urânio": potência de irradiação, de revelação. Não se pode, a meu ver, julgar um objeto histórico só pelo tamanho, sem saber o que é capaz de fazer dizer. Em Le village des cannibales, eu me preocupava com um pequeno acontecimento.

Quanto aos sinos, aí está um bom exemplo do inatual. Há, hoje, mais sinos do que no século XIX: os sinos são mais bem feitos, têm um alcance maior. E, no entanto, você não os ouve. Não os ouve porque não os escuta. E você não os escuta, porque não tem necessidade de ouvi-los. Se você não tivesse outra coisa a não ser os sinos para marcar o tempo, para lhe assinalar os acontecimentos, então você os ouviria. Isso coloca o problema naquele campo da história da sensibilidade do qual falamos, da história da atenção.

\section{SOBRE ALGUNS TRABALHOS RECENTES}

LV: Do inatual ao inesperado, chegamos à sua atualidade. O senhor trabalha há algum tempo sobre um assunto pelo menos original: a sensibilidade à meteorologia. Explique-nos o que recobre esse campo de estudo.

AC: É, por enquanto, um projeto que eu só abordei em pequenos artigos, mas que me parece muito importante. Hoje, os programas de televisão mais assistidos são as previsões do tempo. $\mathrm{O}$ assunto mais freqüente nas conversas telefônicas é a meteorologia. E nas cartas também. Isto pode parecer insignificante, porque é também o assunto para quebrar o gelo. Uma expressão como: "Oh, está frio, hoje", quer dizer que vamos nos falar, mas que isso não tem nenhum interesse. Uns ingleses chegaram a notar que essa era a maneira mais comum de evitar as discussões políticas. Quando se coloca a discussão sobre o terreno do tempo - embora a canícula seja política, agora! —, é uma maneira de dizer: "não vamos abordar os assuntos que aborrecem".

No entanto, há, hoje em dia, uma meteo-sensibilidade extremamente forte. Um antropólogo, Martin de la Soudière, passeia há dez anos na França para conhecer nossa meteo-sensibilidade. ${ }^{26}$ Ele notou que há pessoas que assistem até dez vezes por dia, e até um pouco mais, às previsões do tempo. Essa meteo-sensibilidade diz muitas coisas, de fato. E há um momento da história em que surgiu, ao que parece. Já era presente em madame de Sévigné — há, 
eu creio, 476 ocorrências nas suas cartas —, mas não preocupa muito o século XVII, fora a preocupação com as colheitas. E há aquela frase de Rousseau: "Eu vou colocar um barômetro na minha alma". Os românticos estabelecem então uma homologia entre a variabilidade do eu e a variabilidade do tempo. Isto é, que alguma coisa nas variações do tempo remete às variações do humor, às variações das disposições interiores, às variações íntimas.

Interessar-se pela meteorologia, é, evidentemente, uma maneira de se colocar à margem da história, é não se interessar pela grande história. E, no entanto - vou imitar Lucien Febvre —, não temos uma história da chuva, mal temos uma história da névoa, não temos uma história das tempestades. Eu li simplesmente um estudo sobre a névoa. ${ }^{27} \mathrm{~A}$ autora, que conduziu uma pesquisa entre quinhentas pessoas, constata que as moças gostam mais, hoje em dia, da névoa que os rapazes. Isso significa que um homem e uma mulher não representam a névoa da mesma forma. Além disso, há, também, as representações dos fenômenos meteorológicos que não têm correspondência com a realidade. Se eu pergunto a você, por exemplo: "há névoa em Le Grand Meaulnes? ${ }^{28 ",}$ você tenderá a dizer "sim". Na verdade, não há. E se eu lhe digo: "há névoa em Macbeth?", você tenderá também a dizer "sim". Ora, isso parece ser imaginário. É o contexto que nos incita a dizer "deve haver", "havia névoa”. O imaginário da névoa não corresponde, portanto, à observação meteorológica da névoa: você sabia que não há mais névoa na Inglaterra, em média, do que nas regiões situadas no eixo Alençon-Arras? É nesse ponto que a palavra "névoa" inquieta. Nos contos, sua simples evocação serve para nos fazer entrar num outro mundo, um mundo imaginário. Aí está um belo tema. Ora, não há tese de história sobre essa meteo-sensibilidade histórica, que faz parte da história das sensibilidades. Eu creio que há, aí, belos temas para os jovens historiadores desenvolverem. Mas haveria tantos outros...

\section{LV: O senhor pode dar exemplos?}

AC: No meu livro sobre a história da prostituição na França, Les filles de noce, não se discute muito a sexualidade. Desafio você a encontrar, nas quinhentas páginas, a menor referência a uma prática. Ou tão pouco... há, por exemplo, a aprendizagem da felação por rapazes na casa de prostituição de Château-Gontier, segundo o doutor Homo. De fato, eu quis escrever a história da miséria sexual masculina, fazendo a história da prostituição. Eu queria compreender porque tantos homens desejavam a presença de prostitutas. Daí o subtítulo: "miséria sexual e prostituição no século XIX”. Não é, portanto, 
uma história da sexualidade. Mas: "uma história da sexualidade é possível?". Eu altero aí uma questão de Michelle Perrot: "uma história das mulheres é possível?”. Evidentemente, há Michel Foucault: 150 páginas geniais em A vontade de saber. E depois, pouca coisa. Sylvie Chaperon observou recentemente que se escreveu muita coisa sobre a sexualidade, mas que se esqueceram os atos, isto é, o encontro dos corpos. É, evidentemente, um desafio; tanto mais que isso transgride as normas da conveniência universitária. Quando comecei a preparar Les filles de noce, em 1975, a palavra prostituição não constava no índice bibliográfico da história da França.

Ora, parece-me que, para a primeira metade do século XIX, há fontes que permitem aproximar certas coisas. Penso, em particular, nas observações clínicas dos médicos, que estudei muito. Como escreveu Michel Foucault, a coisa mais importante do mundo, para a primeira metade do século XIX, são efetivamente as relações sexuais. Quando os médicos defrontam-se com uma doença, perguntam-se se ela não vem da maneira pela qual se faz amor. Perguntam freqüentemente, um pouco como os confessores: "Você se masturbou na adolescência? Quantas vezes? Você praticou o coito?”. Alguns perguntam “Como?", porque pensam nas conseqüências que isso poderia ter na doença em estudo: “Você praticou a abstinência?". Hoje, evidentemente, isso faz sorrir. Aí está mais um exemplo de anacronismo psicológico: é preciso levar a sério todas aquelas interrogações e todos os conselhos que os médicos - inesgotáveis no assunto - nos dirigem: as coisas a fazer ou a evitar. Estudando aquelas fichas, conhece-se a idade da defloração, que é sistematicamente perguntada às meninas do povo admitidas no hospital. Novamente, é preciso voltar para a escrita de si. Ora, esta é muito dissimétrica: os homens do século XIX gostam muito de contar vantagens, de contar suas façanhas: Flaubert, nem se fala, quanto a Michelet, ele conta o número de suas relações sexuais com a mulher durante anos. As mulheres, por sua vez, demonstram conveniência e pudor. Não há praticamente nenhuma indicação nos seus diários íntimos.

Há, também, alguns etnógrafos que passearam pelas aldeias e que viram coisas. Não se pode saber o que foi dito em confissão durante a primeira metade do século XIX. Sabe-se que é normativo, isto é, o que não se deve fazer, ou o que se pode fazer. Há, todavia, uma exceção: é o padre de Ars, que confessava 17 horas por dia. Ele não escrevia, mas era um confessor tão bom que os diretores espirituais recorriam a ele quando tinham problemas. E estão conservadas em Ars, segundo Philippe Boutry, quinhentas cartas evocando casos desesperados. Ele estudou o caso de irmã Marie Zoé, por exemplo, com toda uma série de aventuras: estuprada por seu tio, amante de seu diretor es- 
piritual, praticava a masturbação etc. Tudo isso era contado para o padre de Ars. Não se conhece, é claro, sua resposta, mas é um tipo de documento excepcional para o século XIX.

Foucault teve o gênio de se dar conta de que aquele século colocava a sexualidade acima de tudo, e que, por conseguinte, ela governava a parte física e a parte moral do homem, sua história natural, também. O que me interessa é o período anterior à patologização que se desenvolve a partir de 1860 aquele que Foucault estuda. Os médicos do final do século são horrorosos de ler. São apenas perversões e fetichismo. Michel Foucault demonstrou que aquele final de século quis criar uma ciência do sexo, uma sexologia fundada na taxonomia das perversões. É sinistro. Em compensação, tudo está para ser escrito sobre a primeira parte do século.

LV: Caro professor, obrigado por esta entrevista...

AC: Permita-me um último comentário. Se eu tivesse um conselho a dar para aqueles que farão história, que serão professores de história, seria de tentar mudar de objeto de estudo ao longo das décadas. Não se deve fazer sempre a mesma coisa, para que o prazer não se embote. Este é meu conselho... é um pouco rude.

\section{NOTAS}

${ }^{1}$ VIDAL-NAQUET, P. Le choix de l'histoire. Paris: Arléa, 2004, p.29.

${ }^{2}$ DUPEUX, G. Aspects de l'histoire sociale et politique du Loir-et-Cher, 1848-1914. Paris: EPHE, 1962.

${ }^{3}$ CORBIN, A. Le village des "cannibales". Paris: Aubier, 1990.

${ }^{4}$ CORBIN, A. Le miasme et la jonquille, odorat et imaginaire social. Paris: Aubier-Montaigne, 1982. Tradução brasileira: Saberes e odores, São Paulo, Companhia das Letras, 1987.

${ }^{5}$ CORBIN, A. Le territoire du vide: l'Occident et le désir de rivage (1750-1840). Paris: Aubier, 1988. Tradução brasileira: Território do vazio. São Paulo, Companhia das Letras.

${ }^{6}$ CORBIN, A. Les cloches de la terre: paysages sonores et culture sensible dans les campagnes au XIX ${ }^{e}$ siècle. Paris: Albin Michel, 1994.

${ }^{7}$ CORBIN, A. Historien du sensible, entretiens avec Gilles Heuré. Paris: La Découverte, 2000.

${ }^{8}$ FEBVRE, L. "La sensibilité et l'histoire". In: Combats pour l'histoire. Paris: Armand Colin, 1965. 2.éd., p.221-38. 
${ }^{9}$ FEBVRE, L. Le problème de l'incroyance au XVI siècle. La religion de Rabelais. Paris: Albin Michel, 1942.

${ }^{10}$ ELIAS, N. La civilisation des mours. Paris: Calmann-Lévy, 1973 (éd. originale: 1939).

${ }^{11}$ MANDROU, R. Introduction à la France moderne (1500-1640). Essai de psychologie historique. Paris: Albin Michel, 1961.

${ }^{12}$ SUSKIND, P. Le parfum. Paris: Fayard, 1986.

${ }^{13}$ CORBIN, A. Les filles de noce. Misère sexuelle et prostitution (19e siècle). Paris: AubierMontaigne, 1978.

${ }^{14}$ CHEVALIER, L. Classes laborieuses et classes dangereuses à Paris, dans la première moitié du XIX siècle. Paris: Plon, 1958.

${ }^{15}$ CORBIN, A. L'avènement des loisirs. Paris: Aubier, 1995.

${ }^{16}$ GURVITCH, G. Déterminismes sociaux et liberté humaine. Vers l'étude sociologique des chemins de la liberté. Paris: PUF, 1955.

${ }^{17}$ O dia do Armistício (final da Primeira Guerra Mundial, 1918) e a rendição da Alemanha (na Segunda Guerra Mundial, 1945), respectivamente. [N.E.]

${ }^{18}$ CHALINE, J.-P. La bourgeoisie rouennaise au XIX' siècle. Lille: ANRT, 1985; Sociabilité et érudition: les sociétés savantes en France: Paris: éd. du CTHS, 1995.

19 "Dois cavalos" e "três cavalos", carro popular nos anos 50-70, um pouco semelhante ao 'fusca'. [N.T.]

${ }^{20}$ PAQUOT, T. L'art de la sieste. Paris: Zulma, 1998.

${ }^{21}$ DELATTRE, S. Les douze heures de Paris: la nuit à Paris au XIX siècle. Paris: Albin Michel, 2000.

${ }^{22}$ CORBIN, A. Le monde retrouvé de Louis-François Pinagot: sur les traces d'un inconnu (1798-1876). Paris: Flammarion, 1998.

${ }^{23}$ CORBIN, A. "La relation intime ou les plaisirs de l'échange”. In: ARIẼS, Ph., DUBY, G. (Dir.) Histoire de la vie privée, Tome 4, "De la Révolution à la grande guerre”, volume dirigé par Michèle Perrot. Paris: Seuil, Coll. Points Histoire, 1999 (1.éd.: 1987), p.461-519.

${ }^{24}$ AUDOIN-ROUZEAU, S., BECKER, A. 14-18, retrouver la guerre. Paris: Gallimard, 2003.

${ }^{25}$ DUPRONT, A. L'histoire et l'historien. Paris: Fayard, 1964.

${ }^{26}$ DE LA SOUDIÈRE, M. Au bonheur des saisons. Voyage au pays de la météo. Paris: Grasset, 1999.

${ }^{27}$ ARNODIN-CHEGARAY, L. À la poursuite du brouillard. Enigmes et mystères. Mémoire de DEA, Université de Paris VII, 1997.

${ }^{28}$ Romance de Alain-Fournier. [N.T.] 